\title{
Annual material processing by a salt marsh- estuarine basin in South Carolina, USA
}

\author{
R. F. Dame ${ }^{1}$, J. D. Spurrier ${ }^{2}$, T. M. Williams ${ }^{3}$, B. Kjerfve ${ }^{4}$, R. G. Zingmark ${ }^{4}$, \\ T. G. Wolaver ${ }^{4}$, T. H. Chrzanowski ${ }^{5}$, H. N. McKellar ${ }^{4}$, F. J. Vernberg ${ }^{4}$ \\ ${ }^{1}$ Department of Marine Science, Coastal Carolina College, Conway, South Carolina 29526, USA \\ ${ }^{2}$ Department of Statistics, University of South Carolina, Columbia, South Carolina 29298, USA \\ ${ }^{3}$ Belle W. Baruch Forest Science Institute, Clemson University, Georgetown, South Carolina 29442, USA \\ ${ }^{4}$ Belle W. Baruch Institute for Marine Biology and Coastal Research, University of South Carolina, Columbia, \\ South Carolina 29208, USA \\ ${ }^{5}$ Department of Biology, University of Texas at Arlington, Arlington, Texas 76019, USA
}

\begin{abstract}
A synthesis of a comprehensive annual study of material processing in the Bly Creek marsh-estuarine basin is described. The project design provides statistical estimates of material fluxes for the water column, salt marsh, and oyster reef subsystems. Fluxes from a freshwater stream, groundwater, and rain are also presented. Material processing by the Bly Creek marsh-estuarine basin is constituent-and subsystem-specific. Inflows of material via rain, streamwater, and groundwater are small and relatively unimportant compared to tidal fluxes. The salt marsh dominates the basin in aerial extent and in terms of net material fluxes. Most constituents exhibit significant net annual import to the salt marsh. Only DON is exported from the marsh and from the basin at significant levels. The salt marsh appears to recycle most of the nitrogen and phosphorus needed for marsh grass primary production. Sufficient inorganic particulate material is imported to allow the salt marsh to maintain its elevation with respect to ongoing sea-level rise. As a result of metabolic processes, the oyster reef imports particulate materials and releases dissolved nutrients. The reef is a significant consumer of chl a and produces enough dissolved inorganic nitrogen and phosphorus to support water column primary production. The $\mathrm{N}$ : P ratio of Bly Creek dissolved inorganic nutrients is lower than that of North Inlet or ocean waters and implies nitrogen conservation or mobilization of particulate phosphorus into orthophosphate. In contrast to human-impacted coastal systems, this pristine basin reduces the N:P ratio as water passes through it. Differences in the N:P ratio are probably the result of DON export, denitrification, and phosphorus import by the basin.
\end{abstract}

\section{INTRODUCTION}

In the study of any system, the scale of the observations is important to understanding the processes producing the observed behavior. Often processes at a lower level of organization (i.e. the salt marsh) are used to explain system behavior at a higher level (i.e. the estuary). In marsh-estuarine systems, 2 approaches have been used to determine the functioning of the system and its components. The earliest attempts involved the indirect determination of production and consumption budgets; any imbalances were attributed to the export or import of materials (i.e. system behavior) (Teal 1962, Day et al. 1973, Pomeroy \& Wiegert 1981, Hopkinson 1985). Another approach involves the measurement of material and water fluxes through a corss-section of a creek or inlet with internal processes interpreted from total system flux behavior
(Woodwell et al. 1977, Valiela \& Teal 1979, Dame et al. 1986). Because both approaches leave doubts concerning the behavior of the systems and subsystems, we used a combined approach with total system and major subsystem components being observed simultaneously using a statistical design. This approach was applied to the Bly Creek salt marsh-estuarine ecosystem in North Inlet, South Carolina, USA. In addition, we offer a synthesis and explanation of the processing of carbon, nitrogen, and phosphorus by this marsh-estuarine ecosystem from published substudies and previously unpublished data.

\section{MATERIALS AND METHODS}

Site description. The Bly Creek system (Fig. 1) is a well-defined, pristine tidal basin within the North Inlet 


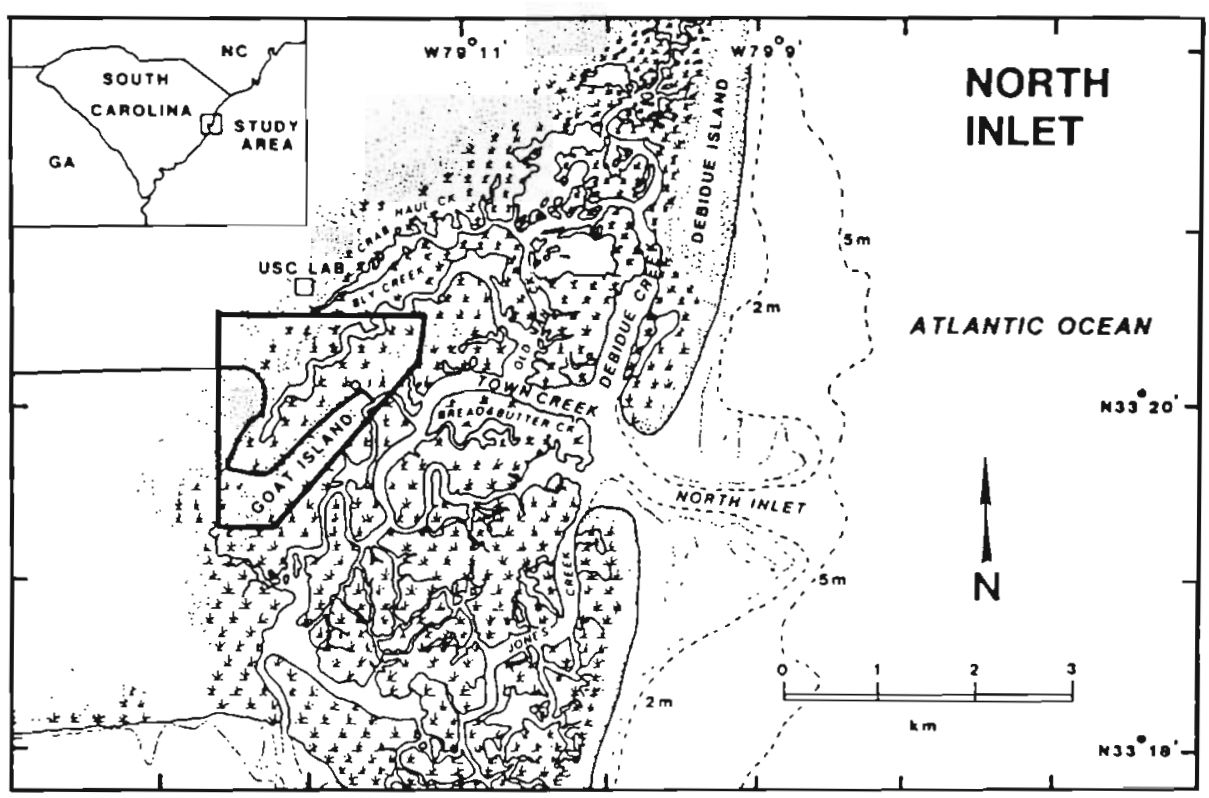

a

b

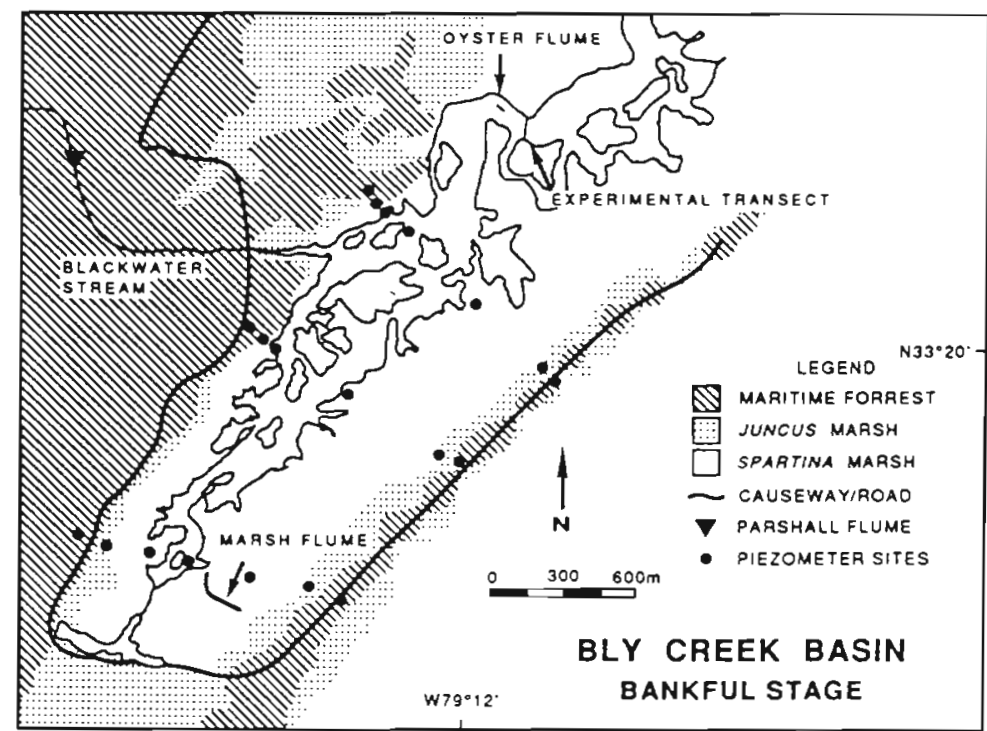

Fig. 1. (a) Location map for North Inlet and Bly Creek. (b) Bly Creek at bankful stage with sampling sites noted
(3200 ha), South Carolina, marsh-estuarine system $\left(33^{\circ} 20^{\prime} \mathrm{N}, 79^{\circ} 10^{\prime} \mathrm{W}\right)$. The basin is bounded by 2 relic beach ridges with narrow stands of pine trees and is a geologically young system developing from the upslope migration of sea level (Gardner \& Bohn 1980, Eiser \& Kjerfve 1986). A small blackwater (fresh) stream draining about 395 ha of pine-oak forest flows into Bly Creek. The Bly Creek study area encompasses 66 ha, with Spartina alterniflora marsh dominating 53.2 ha. Tidal creek bottom covers 12.8 ha and dense oyster reefs, dominated by Crassostrea virginica, cover 0.1 ha. Water temperatures vary seasonally from 8 to $31^{\circ} \mathrm{C}$ and salinity varies from 15 to $35 \mathrm{ppt}$, with depressed salinities common during the rainy season (i.e. winter).

Hydrodynamic setting. As with the other water bodies in the North Inlet system, Bly Creek is vertically well mixed and tides are semidiurnal with a mean range of $1.4 \mathrm{~m}$. Maximum water velocities may exceed $1 \mathrm{~m} \mathrm{~s}^{-1}$ and are greatest on ebbing tides. In addition to tidal flow and freshwater input from the blackwater stream, water also enters the system from rainfall and groundwater flow. At mean low water, $2500 \mathrm{~m}^{3}$ of water remains in the system, which amounts to $0.7 \%$ of the volume at basinful stage when the entire marsh is 
flooded. Sheet flow is a negligible fraction of the total water balance for this system for all but the highest tides (Eiser \& Kjerfve 1986). The flow dynamics of the Bly Creek system are completely dominated by tidal forcing.

Sampling design. The Bly Creek system is a large, structurally complex system, and interacts with the land, atmosphere and adjacent portions of North Inlet estuary. A comprehensive determination of material fluxes requires a number of different methodologies, utilizing different sampling time scales which are integrated to the same annual scale. Thus, not only were water column material fluxes within Bly Creek measured, but fluxes to and from the salt marsh and oyster reef, and input fluxes from rain, blackwater stream, and groundwater were determined. A major theme of this study is to attempt to reduce through sampling design the large amount of variability associated with net flux estimates in previous estuarine studies (Kjerfve \& Wolaver 1988) and provide reliable standard errors and tests of significance.

Our study was conducted from 20 June 1983 to 19 June 1984. Net material fluxes between the Bly Creek area and the adjacent North Inlet estuary and the material exchanges between the creek and the salt marsh and oyster beds were determined simultaneously on 34 of the 707 tidal cycles which occurred during this period (about every 10.2 d). Spurrier \& Kjerfve (1988) demonstrated that this is a sufficiently large number of cycles to ensure statistical significance. We anticipated that there would be periodicities in the net fluxes corresponding to annual, lunar fortnightly, and solar diurnal and semidiurnal cycles, in addition to nonperiodic variations due to storm events, wind conditions, and temperature fronts. Weather variables were recorded for all 707 tidal cycles and used as predictor variables in regression estimates of annual net fluxes (Spurrier \& Kjerfve 1988).

Creek cross-section. To determine the flux of materials between the Bly Creek basin and the adjacent North Inlet estuary, we established a $53 \mathrm{~m}$ wide transect across the creek (Fig. 1) from which measurements were made. The average water depth at mean tide height is $1.33 \mathrm{~m}$ at this portion of Bly Creek. A preliminary study (Kjerfve \& Wolaver 1988) indicated that 2 samples (one near the bottom and a second at middepth) taken from an anchored boat in the middle of the transect adequately represented fluxes through the transect. We measured water velocities with current crosses at depth increments of $0.5 \mathrm{~m}$ from the creek bottom to the water surface (Kjerfve 1982) and corrected for flow direction variations with observations of surface flow using surface ribbon streamers (see Kjerfve \& Wolaver 1988 for a detailed description). We multiplied the corrected water velocities by transect width and time-varying depth and summed the products over the cross-section to yield instantaneous creek discharge. We computed the instantaneous mass fluxes (IMF) similarly by multiplying the material concentrations by the corresponding instantaneous discharge, station width and depth values, and summing over the cross-section. We then integrated the IMF values for a given tidal cycle using a sine-cosine model (Wolaver et al. 1985, Kjerfve \& Wolaver 1988) to obtain net material fluxes per tidal cycle.

Salt marsh flume. To study material exchange between the salt marsh and the adjacent Bly Creek during tidal inundation, we built a flume $140 \mathrm{~m}$ long and $20 \mathrm{~m}$ wide $\left(280 \mathrm{~m}^{2}\right)$ across a portion of Spartina alterniflora marsh near the upper reaches of the Bly Creek basin (Fig. 1). The flume consisted of 2 parallel walls (removable plastic sheets), which channeled tidal water from the edge of the creek across the various height forms of Spartina (Wolaver et al. 1985). At each sampling, we took water samples and made tidal height measurements near the mouth of the flume adjacent to the tidal creek. We combined tidal height measurements with a knowledge of marsh topography to estimate the instantaneous discharge of water onto and off of the marsh (Eiser \& Kjerfve 1986). To obtain instantaneous mass fluxes (IMF), we multiplied the instantaneous discharge estimates by the material concentrations and then integrated these values over a complete tidal cycle to obtain the net material transport (see Wolaver et al. 1985, Spurrier \& Kjerfve 1988 for details).

Salt marsh weir. To determine the flux of materials from the salt marsh during low tide exposure, a small creek ( $2 \mathrm{~m}$ wide $\times 15 \mathrm{~cm}$ deep), which drained an area of about $9000 \mathrm{~m}^{2}$ adjacent to the salt marsh flume, was dammed and a V-notched weir installed. Water flow through the weir was measured and water samples taken on each of the 34 observed tidal cycles. We calculated per cycle material fluxes by multiplying concentrations by water discharge and assumed these values represented each tidal cycle for the time between observations

Oyster reef tunnel. Because of the high density of animal biomass on and the large volume of tidal water passing over the oyster reefs, we developed a portable $10 \mathrm{~m}$ long Plexiglas tunnel covering $7.9 \mathrm{~m}^{2}$ to determine the uptake and release of materials from this subsystem. As there was continuity of water flow through the tunnel, we estimated water flux from water velocity measurements calibrated to the tunnel's crosssectional area. Paired water samples (input end and output end) were taken for material concentration estimates. By determining the difference between input and output concentrations and multiplying the difference by water flux, we were able to compute IMF 
for the oyster reef. Dame et al. (1984) discuss the details of tunnel design and flux calculations.

Blackwater stream. The input of water from the blackwater stream to Bly Creek was measured continuously using a Parshall flume (Fig. 1) (Parshall 1950). Because earlier studies (Wolaver \& Williams 1986) showed that most stream flow occurred during rainstorms, we sampled one stormflow event per month every $2 \mathrm{~h}$. Because these streams have very little slope and have sandy bottoms, this initial study found negligible amounts of particulate materials and these components were not measured in the annual study. Net monthly fluxes were calculated by multiplying the monthly discharge by streamwater material concentrations.

Groundwater. Bly Creek receives groundwater input from a shallow aquifer located in the surrounding salt marsh and beach ridge sediments. We determined groundwater flow gradients with 108 piezometers installed at varying depths along 3 transects across the Bly Creek basin (Fig. 1). The sites were sampled every other month for piezometric pressure and material concentrations. Monthly and annual groundwater fluxes were calculated by multiplying material concentrations by groundwater discharge (as calculated by the Darcy equation).

Rainwater. We estimated rainwater input to the Bly Creek basin, i.e. open water and marsh, from a weighing-type rain gauge located $800 \mathrm{~m}$ west of the basin. After each rainstorm, we took water samples from the gauge and measured them for dissolved nutrient concentrations. The collected rainwater and material concentrations were used to estimate monthly and annual material inputs.

Analytical methods. Water samples $(200 \mathrm{ml})$ were filtered through Whatman GF/C filters. These filters were heated until dry in an oven $\left(60^{\circ} \mathrm{C}\right)$ and weighed. Inorganic sediment concentrations were determined by subtracting the weight of the filter after heating in a muffle furnace for 4 to $5 \mathrm{~h}$ at $450^{\circ} \mathrm{C}$ from the previous filter weight

A water sample $(20 \mathrm{ml})$ was filtered through precombusted Whatman $25 \mathrm{~mm}$ GF/C filters which were passed over concentrated $\mathrm{HCl}$ fumes for $20 \mathrm{~s}$ to remove the inorganic carbon fraction, inserted into ampules, and frozen for particulate organic carbon (POC) analysis. The filters were later dry combusted using CuO as an oxidant (Oceanographic International, unpubl. technique) with the resultant $\mathrm{CO}_{2}$ measured by infrared adsorption using an Oceanographics International carbon analyzer (Model 524c). An additional $200 \mathrm{ml} \mathrm{sam-}$ ple was filtered through a Whatman $47 \mathrm{~mm}$ GF/F filter with the filtrates refrigerated until dissolved organic carbon (DOC) determination with a Beckman carbon analyzer (Model 915A).
Ammonium concentrations were measured by the phenolhypochlorite method (Solorzano 1969) on a Technicon AutoAnalyzer (Glibert \& Loder 1977). Nitrate + nitrite was determined by cadmium reduction and autoanalysis of nitrite (Glibert \& Loder 1977). Total nitrogen and total dissolved nitrogen were determined by persulfate oxidation on an unfiltered and filtered sample, respectively (D'Elia et al. 1977), followed by nitrate + nitrite analysis.

Orthophosphate was determined using the singlereagent method of Murphy \& Riley (1962). Total phosphorus was measured by digesting the appropriate filtered and unfiltered samples via the alkaline persulfate technique of Glibert \& Loder (1977). Particulate phosphorus was calculated by subtraction.

Total microbial biomass was estimated from adenosine triphosphate (ATP) concentrations. A boiling Tris buffer was used to extract ATP from material collected on Whatman GF/F filters. Extractions were assayed by the luciferin-luciferase technique using an SAI-3000 photometer.

Chlorophyll a (chl a) analyses were done by standard fluorometric techniques using the freeze-thaw acetone extraction procedure of Glover \& Morris (1979). Determinations were made on a Turner-111 fluorometer.

Statistical approach. In calculating annual net flux estimates for the tidal creek, salt marsh, and oyster reef, we utilized the statistical technique of regression estimation (Cochran 1977, p. 189-200, Spurrier \& Kjerfve 1988). This technique considers a year as a finite population of tidal cycles. Annual net flux can be estimated using a regression estimator. Thus, for the 3 subsystem fluxes, 34 tidal cycles were observed out of a total of 707 in the sample period. To estimate net material transport on each tidal cycle during the year, a set of 24 potential predictor variables were measured for each of the 707 tidal cycles (Table 1). Because there were $2^{24}$ subsets of predictor variables to consider, stepwise regression was performed first, to reduce the number of subsets considered. This smaller set of predictor variables was further refined by running all possible regressions and selecting the model that produced the minimum value of the Mallows (1973) Cp statistic. The regression estimate of net annual flux is equal to the sum of the predicted flux values for the 707 tidal cycles.

The purpose of the regression model is to provide the best estimate of the annual net flux of a constituent. This method has a smaller standard error than the traditional method of averaging individual tidal cycle estimates and multiplying by the total number of tidal cycles. Thus, variability is explained by regression estimation and this allows us to establish the direction of net flux with tight confidence bounds on annual net flux. 


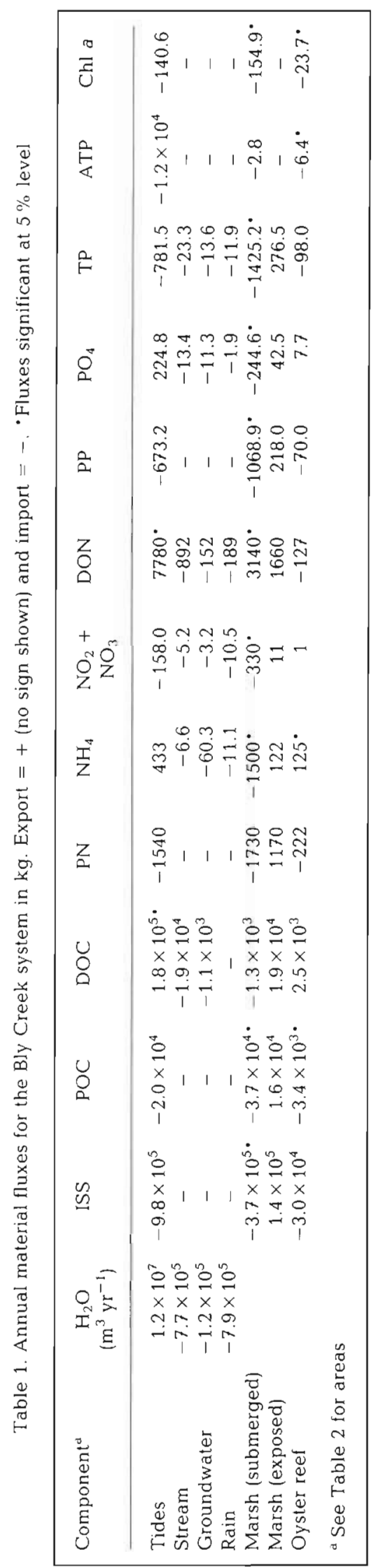

\section{RESULTS}

\section{Tidal water flux}

Due to its strong influence on material transport, the water budget is the most important component in the determination of material flux in tidal waters. The regression estimate for water discharge from the Bly Creek basin during the study is not statistically different from zero. The estimated annual discharge from this model is $1.15 \times 10^{7} \mathrm{~m}^{3}$ with a standard error of 8.01 $\times 10^{6} \mathrm{~m}^{3}$. In an associated but separate study, Eiser \& Kjerfve (1986) determined that sheetflow in the Bly Creek basin is a negligible fraction of the total water balance for all but the highest tides. The Eiser \& Kjerfve (1986) measurements were made during an average neap tide. Their estimate of $2500 \mathrm{~m}^{3}$ per tidal cycle $\left(1.8 \times 10^{6} \mathrm{~m}^{3} \mathrm{yr}^{-1}\right)$ sheetflow is thus hardly representative for the entire year. Since the measured water imbalance only corresponds to a net basin export of $0.36 \mathrm{~m}^{3} \mathrm{~s}^{-1}$, all of this flow could easily be explained by incoming sheetflow during higher portions of the tide, especially during spring tides. Nevertheless, the measured annual water imbalance rate of $0.36 \mathrm{~m}^{3} \mathrm{~s}^{-1}$ is at least 30 times smaller than the average instantaneous discharge during either a flooding or ebbing tide.

\section{Streamwater, groundwater and rainwater fluxes}

Streamwater, groundwater, and rainwater inputs to the Bly Creek basin are all much smaller than tidal water fluxes (Table 1). During the study, the blackwater stream flowed from January to May when local rainfall was heaviest.

Although groundwater flow measurements are difficult to make, both the piezometric and drilling logs data were consistent with a homogeneous sand aquifer resting on a continuous aquiclude. The piezometric pressure data show uniform and parallel flow lines from the pine forest to the salt marsh, indicating that the net flow of groundwater is into the creek.

Rainwater input to the Bly Creek basin is about the same as streamwater flow (Table 1) and occurs mostly during late winter and spring. There were no major storms (hurricanes) during the sample period. Thus, $1.7 \times 10^{6} \mathrm{~m}^{3} \mathrm{yr}^{-1}$ of water entering the basin can be accounted for by streamwater, groundwater, and rainwater.

\section{Inorganic suspended sediments}

Inorganic suspended sediment (ISS) concentrations vary seasonally within the Bly Creek basin, with max- 
imum concentrations ( $85.1 \mathrm{mg} \mathrm{l}^{-1}$ ) occurring in summer (Wolaver et al 1988b). Of the material deposited on the marsh during tidal submergence, an amount equivalent to $38 \%$ is exported by surface flow during low tide exposure (Table 1). The submerged salt marsh is a sink for ISS, but the estimate for tidal water, although consistent in direction, is not statistically significant.

\section{Organic carbon}

Particulate organic carbon (POC) concentrations vary seasonally from 0.63 to $5.3 \mathrm{mgC}^{-1}$, with highest values in late summer (Williams et al. 1991). From the regression estimate, the net flux of POC via tidal waters appears to be into the Bly Creek basin with POC removed by the submerged salt marsh and the oyster reef. Of the POC taken up by the marsh, an amount equivalent to $43 \%$ of this input is returned to the creek during low tide exposure (Table 1). The annual POC net flux by tidal water is not significantly different from zero, but it is of the same magnitude and direction as the net annual uptake by the salt marsh.

Dissolved organic carbon (DOC) varies seasonally in concentration from 2.5 to $11.8 \mathrm{mgC}^{-1}$ (Williams et al. 1991), with lowest values in summer and fall and highest observations in late winter and spring. DOC leaves the basin via tidal flow, with streamwater and groundwater accounting for only $11 \%$ of the observed net export (Table 1). Although the salt marsh appears to export DOC during low tide exposure, the regression estimate of DOC flux from the submerged marsh (flume) is not significantly different from zero. The Bly Creek basin annually exports an order of magnitude more DOC than can be explained by the observed sources.

\section{Nitrogen}

Particulate nitrogen (PN) concentrations vary seasonally in the tidal waters, reaching a maximum $(492$ $\mu \mathrm{gN}{ }^{-1}$ ) in the late spring and summer (Wolaver et al. 1988c). Annually, PN is imported by the Bly Creek basin, but most of this import occurs during the late summer (Wolaver et al. 1988c). The regression estimates of PN flux by tides, marsh flume, and oyster reef tunnel are not statistically significant, but the direction of these fluxes is consistent with the other particulate constituents and our understanding of the systems involved (Table 1).

Ammonium $\left(\mathrm{NH}_{4}\right)$ concentrations in the tidal waters vary seasonally, with highest values $\left(145 \mu \mathrm{gN} \mathrm{l}^{-1}\right)$ in the late summer and early fall (Wolaver et al. 1988c). Although the regression estimate projects (nonsignificant) an annual net export of $\mathrm{NH}_{4}$ via tidal flow (Table
1), seasonally this constituent is imported during the late summer and early fall (Wolaver et al. 1988c). Of the observed subsystems, the submerged salt marsh is a major and significant sink for $\mathrm{NH}_{4}$, importing considerably more of this constituent than is annually available from surface runoff from the marsh, oyster reef, streamwater, groundwater, and rain (Table 1).

Nitrate + nitrite $\left(\mathrm{NO}_{3}+\mathrm{NO}_{2}\right)$ concentrations were highly variable during the study year (Wolaver et al, $1988 \mathrm{c}$ ). On an annual basis, this constituent is imported to the Bly Creek basin in streamwater, groundwater, and rainwater, and appears to be imported in tidal water (regression estimate not significant). The salt marsh, as indicated by the flume, imports $\mathrm{NO}_{3}+\mathrm{NO}_{2}$ and is more than capable of removing all of this constituent that is potentially imported (Table 1).

Dissolved organic nitrogen (DON), a calculated constituent [total dissolved nitrogen $-\left(\mathrm{NH}_{4}+\mathrm{NO}_{3}+\mathrm{NO}_{2}\right)$ ] varies seasonally, with maximum concentrations (486 $\mu \mathrm{N}^{-1}$ ) occurring in spring and early summer (Wolaver et al. 1988c). There is a statistically significant net flux of DON out of the system in the tidal waters (Table 1) with about $16 \%$ coming from blackwater stream, groundwater, and rain input and $62 \%$ from the salt marsh (submerged and exposed).

\section{Phosphorus}

As with other particulate materials, particulate phosphorus (PP) concentrations are higher in summer (131 $\left.\mu \mathrm{gP}^{-1}\right)$ and lower in winter $\left(13 \mu \mathrm{gP} \mathrm{l}^{-1}\right)$ (Dame et al 1990). Annually, PP is imported into the system in tidal waters (Table 1), but this import is not significantly different from zero. The regression estimate of PP import to the submerged salt marsh flume is significant and, when export during salt marsh exposure is taken into account, describes a net import of $851 \mathrm{kgP}$ by the total salt marsh. Total phosphorus (TP) behaves similarly to PP both in seasonality of concentrations and net flux, except that small amounts enter the basin in streamwater, groundwater, and rain.

Orthophosphate $\left(\mathrm{PO}_{4}\right)$ exhibits seasonal variations in concentration, from $35 \mu \mathrm{gPl}^{-1}$ in summer to $3 \mu \mathrm{gP} \mathrm{l}^{-1}$ in fall (Dame et al. 1990). The estimate for the submerged salt marsh flume indicates a significant import of $\mathrm{PO}_{4}$ with an amount equivalent to $18 \%$ of this inflow exported during low tide exposure. Streamwater, groundwater, and rain can only provide about $11 \%$ of this import

\section{ATP and chlorophyll a}

The regression estimates (nonsignificant) of ATP and chl a suggest these constituents are imported to the Bly 
Creek basin in the tidal waters. The submerged salt marsh flume and oyster reef tunnel took up chl a (regression significant); however, when extrapolated to the entire basin, the reef and marsh subsystems only remove a small portion of the ATP imported by the basin (Chrzanowski \& Zingmark 1986).

\section{DISCUSSION}

\section{Water discharge}

Water and material transport measurements in tidal creeks are made difficult by the reversing tidal flows that are 1 or 2 orders of magnitude greater than the concurrent net flows. Gravitational flow driven by freshwater inputs, residual tidal flow, wind drift, and estuarine storage and emptying due to dynamic coupling to other water bodies are the major physical mechanisms causing net water movements in these systems (Kjerfve \& Wolaver 1988). Bly Creek is an ebbdominated system and appears to have a net discharge of water (not significantly different from zero) to the adjacent estuary. Rainfall, streamwater flow, and groundwater inputs also make small contributions to the water discharge character of this system.

\section{Suspended sediments}

Our studies indicate that ISS undergoes the largest net flux of material in Bly Creek and that the salt marsh is a major sink for this material (Table 1). Most previous studies indicate an export of ISS rather than an import (Axelrad 1974, Boon 1978, Ward 1981), but in their study of the Rhode River estuary, Jordan \& Correll (1986) speculate that large amounts of particulate material are removed by sedimentation onto the creek bottoms. A similar phenomenon may occur in Bly Creek, but the lack of significance in most ISS regression estimates and the ebb-dominated nature of the creek make such estimates speculative.

The import of ISS into the salt marsh surrounding Bly Creek appears sufficient to keep the marsh surface above rising sea level at this location (Wolaver et al 1988a). A significant proportion of the ISS imported to the salt marsh seems to be redistributed by tidal flows after major rainstorms (Wolaver et al. 1988b). At low tide, rain impaction can be an effective mechanism in resuspending and transporting particles (Settlemyre \& Gardner 1977). The resuspended ISS is transported up-creek on the succeeding flood tide, where it can be deposited on the marsh and on the creek bottom, thus reversing the ebb-dominated (export) flow pattern.

\section{Organic carbon}

Unlike our previous observations of the larger North Inlet system which showed POC export (Dame et al. 1986), Bly Creek tidal waters appear to import POC (Table 1). Most of this import seems to be taken up by the salt marsh and to a lesser extent by the oyster reef. As indicated by the import of ATP and chl a, a proportion of the imported POC must be living material, but only the larger cells containing chlorophyll are taken up by the salt marsh and oyster reef subsystems (Table 1). A large proportion of the POC imported to the salt marsh is probably removed during low tide exposure. In a detailed analysis of the salt marsh flume studies, Wolaver \& Spurrier (1988) found that DOC was exported from the marsh during rainstorms in a pattern similar to that observed by Chalmers et al. (1985) at Sapelo Island, Georgia, and Roman \& Daiber (1989) in Canary Creek, Delaware.

Unlike POC, DOC is exported via tidal flows from the Bly Creek basin. Of this exported DOC, some may be throughput from streamwater and groundwater and some is from marsh runoff and release from the oyster reef. The DOC enters the tidal creek from the freshwater stream during periods of freshwater flow, but only accounts for about $10 \%$ of the net flux in tidal water (Wolaver \& Williams 1986). Both this study and the Georgia study (Chalmers et al. 1985) imply that if labile compounds are released directly into the inundating tidal water by Spartina leaves (Turner 1978, Pakulski 1986) or from the marsh surface by decomposition followed by diffusion (Pomeroy et al. 1977), these substances are removed from the water before it leaves the marsh surface. This observation supports earlier work by Gallagher et al. (1976) which suggests that DOC exudates from live Spartina leaves are quickly removed by epiphytic organisms.

DOC export in runoff and seepage has been observed in marsh porewater flux by Howes et al. (1985) and Yelverton \& Hackney (1986). Although the marsh appears to be a source of DOC in our system, it only accounts for a small amount of the DOC exported from the Bly Creek basin. The release of DOC from the oyster reef may offer a clue to the other major source of DOC. The oyster reef system is part of the benthic community or bottom of the tidal creek, but covers only a small proportion of this creek bottom area $(0.8 \%)$. If the non-reef bottom of the creek produces only $50 \%$ of the DOC per unit area which the oyster reef produces, this amount would be sufficient to account for all of the DOC exported from the tidal creek.

It is also pertinent to ask how much of the carbon produced in the Bly Creek basin is exported. The total primary production of the various subcomponents 
Table 2. Net primary production in the Bly Creek basin

\begin{tabular}{|c|c|c|c|c|c|c|}
\hline Subsystem & $\begin{array}{l}\text { Area } \\
\left(\mathrm{m}^{2}\right)\end{array}$ & $\begin{array}{l}\text { Phytoplankton } \\
\left(\mathrm{gC} \mathrm{m}^{-2} \mathrm{yr}^{-1}\right)\end{array}$ & $\begin{array}{l}\text { Microbenthicb } \\
\left(\mathrm{gC} \mathrm{m}^{-2} \mathrm{yr}^{-1}\right)\end{array}$ & $\begin{array}{l}\text { Macrobenthic } \\
\left(\mathrm{gC} \mathrm{m}^{-2} \mathrm{yr}^{-1}\right)\end{array}$ & $\begin{array}{c}\text { Grass }^{\mathrm{d}} \\
\left(\mathrm{gC} \mathrm{m}^{-2} \mathrm{yr}^{-1}\right)\end{array}$ & $\begin{array}{c}\text { Total } \\
\left({\mathrm{gC} y \mathrm{r}^{-1}}^{-1}\right)\end{array}$ \\
\hline Creek & $1.28 \times 10^{5}$ & 265 & 400 & 450 & 0 & $1.43 \times 10^{8}$ \\
\hline Oyster reef & $1.00 \times 10^{3}$ & 0 & 400 & 790 & 0 & $1.19 \times 10^{6}$ \\
\hline Tall marsh & $3.99 \times 10^{4}$ & 0 & 400 & 290 & 2078 & $1.10 \times 10^{8}$ \\
\hline Mid-marsh & $8.46 \times 10^{4}$ & 0 & 400 & 20 & 666 & $1.19 \times 10^{7}$ \\
\hline Short marsh & $4.06 \times 10^{5}$ & 0 & 400 & 10 & 2888 & $1.34 \times 10^{9}$ \\
\hline Total system & $6.61 \times 10^{5}$ & & & & & $1.61 \times 10^{9}$ \\
\hline \multicolumn{7}{|c|}{ "Sellner et al. (1976) } \\
\hline \multicolumn{7}{|c|}{ b Zingmark unpubl. } \\
\hline \multicolumn{7}{|c|}{${ }^{c}$ Coutinho (1987) } \\
\hline \multicolumn{7}{|c|}{${ }^{`}$ Dame \& Kenny (1986) } \\
\hline
\end{tabular}

within the basin is given in Table 2 . Total annual primary production is $1.61 \times 10^{6} \mathrm{kgC}$, with $6.7 \times 10^{5}$ $\mathrm{kgC}$ of this contributed by aboveground production. From these calculations, only about $10 \%$ of the total carbon produced within the system is exported $(1.6 \times$ $10^{5} \mathrm{kgC} / 1.61 \times 10^{6} \mathrm{kgC}$ ), which represents about $24 \%$ of the aboveground production. Since there is very little peat formation in this system (Morris \& Whiting 1986), most of the remaining organic carbon must be decomposing in situ. A general study state budget for carbon in the Bly Creek basin utilizing all estimated and observed annual net fluxes (Fig. 2) shows that only a small amount of the carbon exported in the tidal water is from the salt marsh. Most of the carbon export ( $89 \%$ ) from the basin can be accounted for by primary production of phyto- plankton, macroalgae, and microbenthic algae within the creek.

\section{Nitrogen}

As with POC, PN appears to be imported by the tidal waters and most of this material may be taken up by the oyster reef and salt marsh. A large proportion of the PN taken up by the salt marsh appears to exit during low tide exposure. Thus, it seems that enough PN is imported via tidal water and recycled via runoff from the exposed marsh to account for the material taken up by the submerged salt marsh and the oyster reef.

Of the dissolved inorganic nitrogen, $\mathrm{NH}_{4}$ appears to be exported from the tidal basin and imported to the

\section{CARBON FLUXES $\left(\mathrm{kgC}^{-1} \times \mathrm{IO}^{3}\right)$}

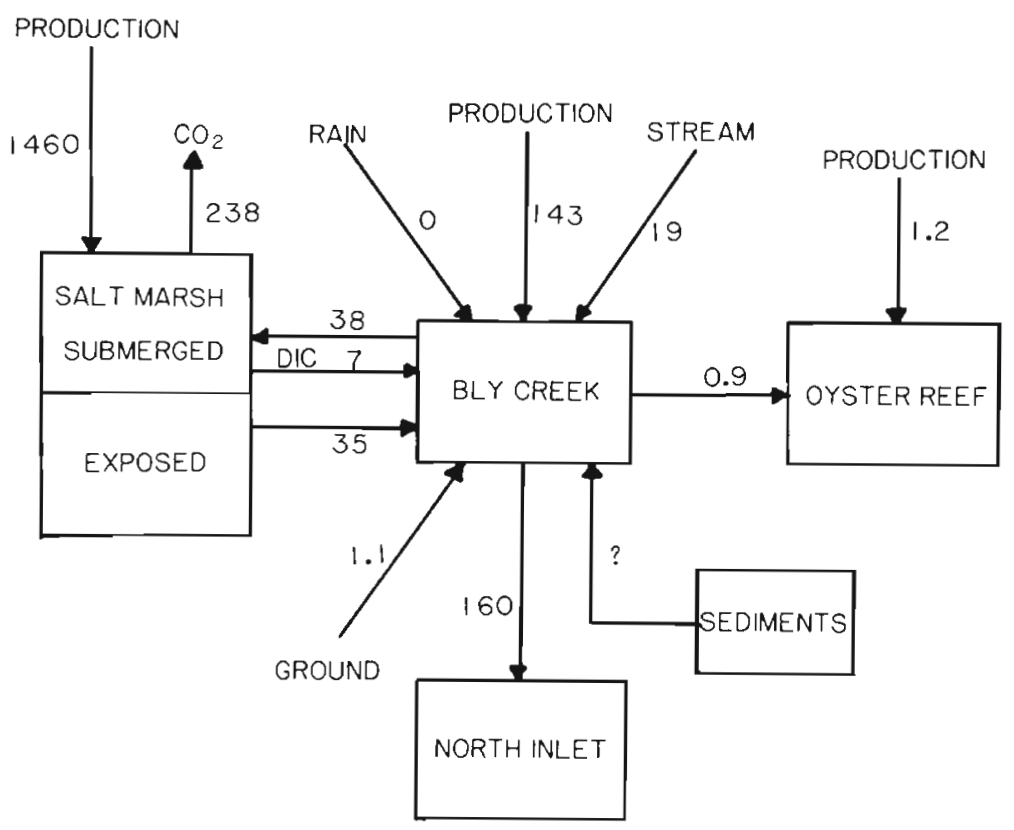

Fig. 2. Carbon fluxes for the Bly Creek system with data from this study and other published reports. All production values are for net primary production adjusted for area. Total system area is $6.61 \times 10^{5} \mathrm{~m}^{2}$ 


\section{NITROGEN FLUXES ( $\mathrm{kgN} \mathrm{yr}^{-1}$ )}

Fig. 3. Nitrogen fluxes for the Bly Creek system with data from this study and other published reports. Total system area is $6.61 \times 10^{5} \mathrm{~m}^{2}$

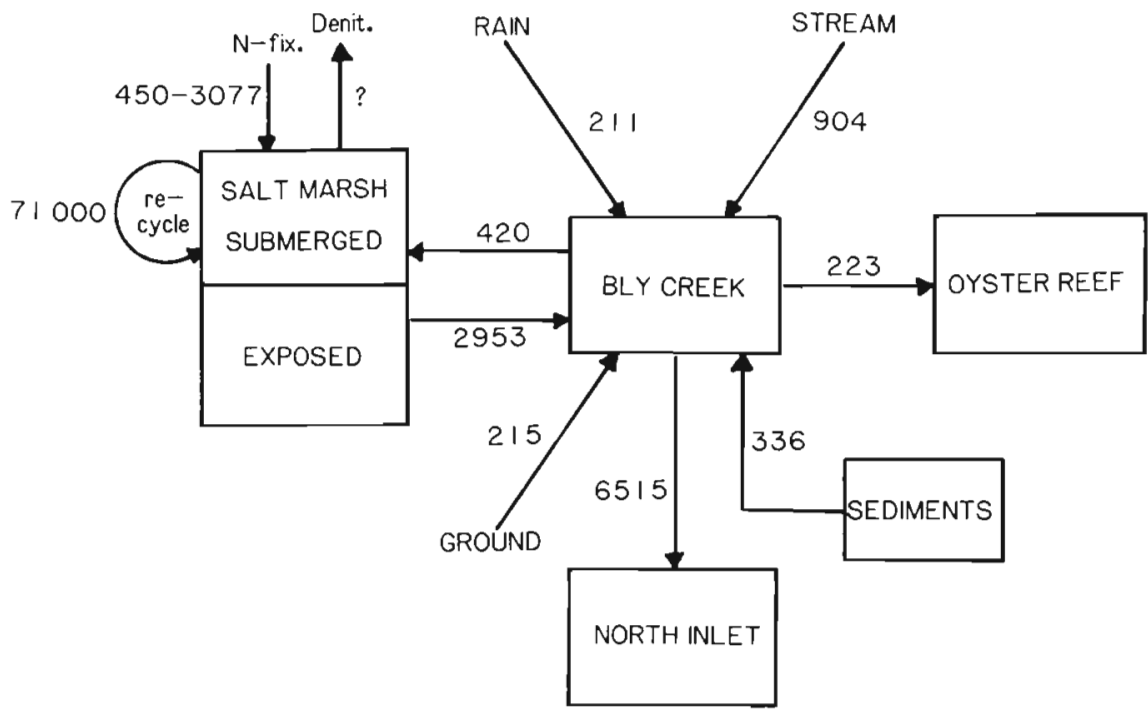

salt marsh at a high rate (Table 1). The large imbalance in $\mathrm{NH}_{4}$ sources to the tidal creek and fluxes to the salt marsh and from the tidal basin implies internal cycling. The tidal creek water column and/or benthic habitat may be additional sources within the basin (Wolaver et al. 1988c). Results from other studies (Agosta 1985, Jordan \& Correll 1985) indicate that seepage from creekbanks during low tide may contribute significant amounts of dissolved nutrients to tidal creeks. In addition, the advective movement of interstitial water from the creek bottom, coupled with diffusion, can supply 3 times as much $\mathrm{NH}_{4}$ as does the exposed marsh to the creek (Whiting \& Childers 1989). Unlike $\mathrm{NH}_{4}, \mathrm{NO}_{3}+$ $\mathrm{NO}_{2}$ is imported into the Bly Creek basin at a rate $(0.23$ $\mathrm{gN} \mathrm{m}^{-2} \mathrm{yr}^{-1}$ ) lower than most of the observed imports of this constituent into other marsh-estuarine systems (Nixon 1980). Within the Bly Creek basin, the salt marsh appears to be capable of removing all of the $\mathrm{NO}_{3}$ $+\mathrm{NO}_{2}$ potentially imported into the basin via tidal exchange, streamwater, groundwater, and rain (Table 1). The estimated $\mathrm{NO}_{3}+\mathrm{NO}_{2}$ import to the marsh appears to be in excess of that supplied by the tidal creek. This excess may come from $\mathrm{NO}_{3}+\mathrm{NO}_{2}$ produced within the water column by nitrification and or the oxidation of $\mathrm{NH}_{4}$

Most of the nitrogen leaving the Bly Creek basin is in the form of DON. Although a large amount of this material enters the tidal waters from streamwater, rain, and groundwater flows, the majority appears to be exported by salt marsh runoff (Table 1). This DON is probably the product of decomposition processes which occur on the salt marsh and gives the marsh, a major primary production zone, a distinctive heterotrophic character (Whiting et al. 1989).

A general steady state nitrogen budget for the Bly Creek basin (Fig. 3) shows a net loss of nitrogen from the Bly Creek basin. However, inputs to the tidal creek explain only $65 \%$ of the nitrogen leaving. Utilizing estimates of nitrogen fixation on the salt marsh of 450 to $3077 \mathrm{kgN} \mathrm{yr}^{-1}$ (Haines et al. 1977, Whiting \& Morris 1986) and material imported during marsh submergence, there is sufficient material to account for the large amount of nitrogen leaving the salt marsh. However, for the system as a whole, there is $2874 \mathrm{kgN}$ of export unaccounted for. This excess may be due to nitrogen fixation in the water column or on the creek bottoms. The net uptake of nitrogen by the oyster reef is probably due to biomass accumulation during the study period (Dame et al. 1989).

\section{Phosphorus}

The Bly Creek system appears to import PP and TP in tidal water and most of this material flux may be attributed to the significant uptake rates of the salt marsh. However, the system as a whole appears to release $\mathrm{PO}_{4}$ even though our estimates indicate the salt marsh is 


\section{PHOSPHORUS FLUXES (kgP yr $\left.{ }^{-1}\right)$}

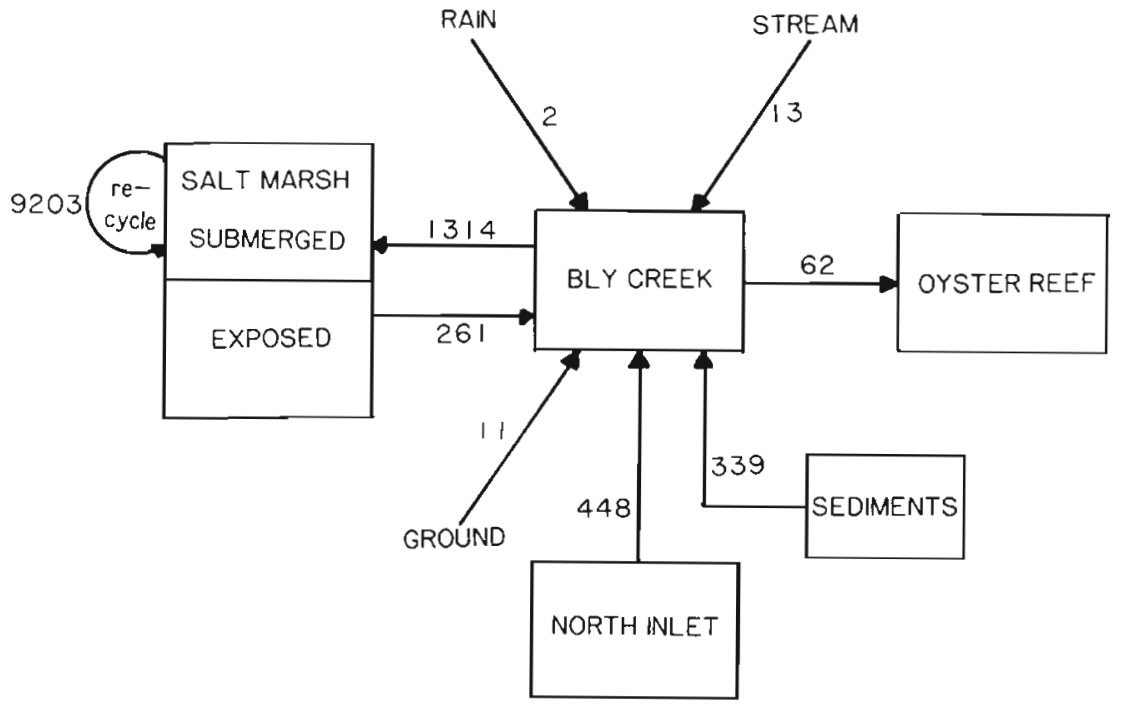

Fig. 4. Phosphorus fluxes for the Bly Creek system with data from this study and other published reports. Total system area is $6.61 \times 10^{5} \mathrm{~m}^{2}$

taking up this constituent (Table 1). This apparent release of $\mathrm{PO}_{4}$ by the system is explained in part by the oyster reef and runoff from the exposed marsh, but another source may be the decomposition processes in the creek bottoms (Agosta 1985, Jordan \& Correll 1985, Whiting \& Childers 1989). In a preliminary study, Whiting \& Childers (1989) observed the advective flux of $\mathrm{PO}_{4}$ from the Bly Creek bottom to be 1.3 times that of the export from the exposed salt marsh. However, estimates of $\mathrm{PO}_{4}$ flux from sediments in a North Carolina estuary (Fisher et al. 1982) are more than twice those of Whiting \& Childers and can more than account for the material necessary to balance the Bly Creek phosphorus budget (Fig. 4). In general, the Bly Creek system appears to import particulate phosphorus which is processed into labile $\mathrm{PO}_{4}$ and then exported.

\section{Microplankton}

Both ATP, which is indicative of all plankton, and chl $a$, which is representative of phytoplankton, appear to be imported into the Bly Creek basin via tidal currents. Most of the chl a is taken up by the salt marsh and the oyster reef, but little of the ATP removal is explained in this manner. Chrzanowski \& Zingmark (1986) noted that in this system the influence of tides on these 2 constituents is different and suggest a change in the microbial assemblage as water rises and falls over the marsh. The uptake of chl a by the oyster reef is likely due to the presence of large numbers of filter feeders which actively remove phytoplankton from the water column. On the marsh, phytoplankton may be consumed by benthos (i.e. marsh mussels, barnacles, etc.) and/or settle out due to low water velocities.

\section{Nutrient ratios}

The ratio of various nutrients can be used as a way to identify unusual fluxes and possible mechanisms of nutrient processing. The standard ratios for comparison are the Redfield ratios (Redfield et al. 1963), that is, $C: N: P=106: 16: 1$. Annual fluxes are used to compute molar elemental ratios, to illuminate the influence of temporal variations in fractionation during organic matter decomposition (Nixon et al. 1976) and because the storage and release of reduced end products may be aperiodic (Balzer 1984). We have not calculated ratios involving organic matter (i.e. POC, DOC, and

Table 3. N:P atomic ratios for the various fluxes in the Bly Creek system including direction of flux: $\mathrm{I}=$ import, $\mathrm{E}=$ export

\begin{tabular}{lcr|}
\hline Flux component & Direction & N:P \\
\hline Streamwater & I & 2.0 \\
Groundwater & I & 12.9 \\
Rain & I & 26.0 \\
Tidal water & E & 2.8 \\
Subraerged marsh & I & 17.1 \\
Exposed marsh & E & 6.7 \\
Oyster reef & E & 37.5 \\
\hline
\end{tabular}


DON), because its composition and what portion is actually metabolizable are unknown.

The N:P flux ratios of reactive nutrients, dissolved inorganic nitrogen $\left(\mathrm{NH}_{4}+\mathrm{NO}_{3}+\mathrm{NO}_{2}\right): \mathrm{PO}_{4}$, as observed in Bly Creek, are shown in Table 3. The tidal creek exports the above reactive nutrients with an N:P ratio of 2.8 which implies a relative enrichment with phosphorus or, more likely, a deficiency of reactive nitrogen due to utilization and/or net loss. While water from the blackwater stream appears to be enriched with phosphorus, the influence of this component is more than offset by the higher ratio in groundwater and rain. The higher ratio in groundwater is thought to be due to the strong adsorption of phosphate by soils and sediments along the travel path of this water (Valiela \& Costa 1988). The elevated value in rainwater is due to the absence of phosphorus and relative enrichment of nitrogen in the atmosphere. The salt marsh seems to be the major influence on the $\mathrm{N}: \mathrm{P}$ ratio of reactive nutrients in the Bly Creek basin. Nitrogen and phosphorus are imported during tidal submergence at a ratio of 17.1 and exported at a much lower ratio, 6.7, during low tide exposure. Since nitrogen has a gaseous form which is lost to the atmosphere, this change in $N: P$ ratio on the salt marsh probably reflects denitrification, preferential burial of nitrogen-rich compounds, conversion to DON or nitrogen-limited growth in the basin system. Phosphorus is not thought to be limiting in turbid salt marsh estuarine systems (Whitney et al. 1981) due to the large quantities of phosphorus sorbed in clay sediments or peats. In Georgia marsh-estuarine systems, phosphorus in the sediments and water is thought to be in equilibrium due to a physicochemical buffer system (Whitney et al. 1981), but the fluctuation of phosphate concentrations over individual tidal cycles in Bly Creek and North Inlet (Wolaver et al. 1984) implies non-equilibrium conditions in the latter systems. If all nitrogen and phosphorus components are considered, then phosphorus seems to be governed by the import of PP and export of $\mathrm{PO}_{4}$ while nitrogen probably enters via nitrogen fixation and is exported as DON. The latter nitrogen fluxes are of much larger magnitudes than those of the reactive nutrients and in effect obscure them.

Optimum (Redfield) N:P ratios do not occur often in estuaries because of the domination of physical factors. In these systems, nitrogen may not accumulate because it is exported to the sea (Schindler 1981) faster than it can be fixed (Ryther \& Dunstan 1971). Low nitrogen fixation may be attributed to the low availability of phosphorus, iron and molybdenum (Howarth 1988), short residence time of water (Schindler 1981, Smith 1984), and high turbulence (Pearl 1985) in estuaries. In Bly Creek, however, there is $2874 \mathrm{~kg}$ of TN export that is unaccounted for that is probably the net excess of nitrogen fixation over denitrification within the basin. Therefore, nitrogen fixation must be fast enough to support this rather substantial imbalance in the measured fluxes.

There is a net release of these reactive nutrients from the oyster reef; however, as in other bivalve systems, phosphorus is preferentially retained (Dame et al. 1989 ), resulting in a high N:P ratio of 37.5 . While the influence of the oyster reef on the system's nutrient budget is larger than that of streamwater, groundwater, or rainwater, it is still not large enough to have a major effect on the N:P ratio of the creek water leaving the system.

The Bly Creek system appears to reduce the N:P ratio as water passes through the basin. This behavior contrasts with other coastal landscape studies where water moving through marshes increased the N:P ratio (Valiela et al. 1978, Jordan \& Correll 1986, Valiela \& Costa 1988); however, all of these studies were on anthopogenically impacted systems while Bly Creek is essentially pristine.

Assuming a standard Redfield ratio for production in the tidal creek, we can calculate the nitrogen and phosphorus demand of the plants in the creek. An estimated $25 \mathrm{kgN} \mathrm{yr}^{-1}$ and $3.5 \mathrm{kgP} \mathrm{yr}^{-1}$ are needed to support creek primary production (Table 2). These amounts of nitrogen can be provided by groundwater, exposed marsh runoff, or oyster reef excretion (Figs. 3 \& 4).

Using a C:N ratio of 34.2 for Spartina and 10 for algae living on the salt marsh (Haines et al. 1977), we calculate the nitrogen demand by the Bly Creek basin salt marsh to be $7.15 \times 10^{4} \mathrm{kgN} \mathrm{yr}^{-1}$. Since nitrogen fixation only provides about $3077 \mathrm{kgN} \mathrm{yr}^{-1}$ at most and the tidal creek puts in $420 \mathrm{kgN} \mathrm{yr}^{-1}$, most of the nitrogen needed for primary production on the marsh seems to come from recycling. Similarly, an N:P ratio of 15.9 for Spartina (Ornes \& Kaplan 1989) allows us to calculate a phosphorus demand of $1.02 \times 10^{4} \mathrm{kgP} \mathrm{yr}^{-1}$. As the tidal creek can only provide about $10 \%$ of this demand, the remainder can be attributed to recycling within the marsh. From these calculations, it is clear that recycling is very important to the functioning of this salt marsh and there is much more turnover than throughput in this system.

The Bly Creek basin is a young marsh-estuarine system developing in response to ongoing relative sealevel rise. As a whole the North Inlet system, on the other hand, is a more mature system with some areas of marsh that have probably existed for up to $5000 \mathrm{yr}$ and other marshes, like Bly Creek, that are immature. Bly Creek has higher primary productivity and exports considerably less material per unit area than North Inlet (Table 4). The higher productivity and nutrient retention of a young system (Bly Creek) as compared to an older 
Table 4. Material fluxes for North Inlet and Bly Creek $\left(\mathrm{g} \mathrm{m}^{-2}\right.$ $\left.\mathrm{yr}^{-1}\right)$. Export $=+($ no sign shown $)$, import $=-$. N:P ratio calculated from fluxes of ammonium + nitrate + nitrite and orthophosphate: Redfield ratio $=16 ;$ marsh grass $=2.9 ;$ oysters (est.) $=5$ to 8

\begin{tabular}{|lcc|}
\hline Component & $\begin{array}{c}\text { North Inlet to } \\
\text { Atlantic Ocean }\end{array}$ & $\begin{array}{c}\text { Bly Creek to } \\
\text { North Inlet }\end{array}$ \\
\hline Production & 1972 & 2436 \\
$\mathrm{DOC}$ & 328 & 250 \\
$\mathrm{POC}_{\mathrm{NH}}$ & 128 & -31 \\
$\mathrm{NO}_{2}+\mathrm{NO}_{3}$ & 6.3 & 0.54 \\
$\mathrm{PO}_{4}$ & 0.9 & -0.27 \\
$\mathrm{~N}: \mathrm{P}$ (atoms) & 1.7 & 0.30 \\
& 10 & 2.1 \\
\hline
\end{tabular}

system (major portions of North Inlet) support the general ecosystem development hypothesis of Odum (1969) and Vitousek \& Reiners (1975). In a young rapidly developing ecosystem, more biomass is being produced and thus nutrient storage is higher than in older systems where growth is lower and fewer nutrients are needed (Vitousek \& Reiners 1975). The higher turnover could be due to the longer residence time for water within the Bly Creek basin as compared to North Inlet as a whole. The $N: P$ ratio 2.1 for reactive nutrients in Bly Creek (this study), as compared to 10 for North Inlet (Dame et al. 1986), implies more nitrogen limitation exists in Bly Creek than in the inlet itself, which has an N:P ratio closer to the open ocean Redfield ratio.

In this study, it is evident that different subsystems or combinations of subsystems influence or control the character of the various material fluxes. The salt marsh seems to dominate nitrogen and phosphorus processing, but seems to be isolated from the other systems with regard to carbon. The oyster reef and the marsh appear to play a major role in the processing of chl $a$, a phytoplankton indicator, but do not seem to influence the fluxes of ATP (which represents the total microbial community). While statistically significant annual material flux estimates are difficult to establish, this study shows that the Bly Creek basin and the marsh in particular are not universal exporters of material, but more generally they are processors and recyclers.

Acknowledgements. The authors are grateful to the students of Coastal Carolina College and the University of South Carolina who assisted in the sampling. The analytical and technical expertise of the staff of the Baruch Marine Field Laboratory was invaluable. L. R. Gardner, C. S. Hopkinson, S. Libes, and A. Miller provided constructive and helpful comments in the development of the manuscript. This work was supported by Grant No. DEB 81-19752 from the National Science Foundation Ecosystem Section. This is publication no. 855 of the Belle W. Baruch Institute for Marine Biology and Coastal Research.

\section{LITERATURE CITED}

Agosta, K. (1985). The effect of tidally induced changes in the creek bank water table on pore water chemistry. Estuar. coast. Shelf Sci. 21: $381-400$

Axelrad, D. (1974). Nutrient flux through the salt marsh ecosystem. Ph. D. thesis, College of William and Mary, Gloucester Point, Virginia

Balzer, W. (1984). Organic matter degradation and bogenic element cycling in nearshore sediment (Kiel Bight). Limnol. Oceanogr. 29: 1231-1246

Boon, J. (1978). Suspended solids transport in a salt marsh creek - An analysis of errors. In: Kjerfve, B. (ed.) Estuarine transport processes. University of South Carolina Press, Columbia, p. 147-159

Chalmers, A., Wiegert, R., Wolf, P. (1985). Carbon balance in a salt marsh: interactions of diffusive export, tidal deposition and rainfall-caused erosion. Estuar. coast. Shelf Sci. 21: $757-771$

Chrzanowski, T., Zingmark, R. (1986). Passive filtering of microbial biomass by Spartian alterniflora. Estuar. coast. Shelf Sci. 22: 545-557

Cochran, W. (1977). Sampling techniques, 3rd edn. Wiley, New York

Coutinho, R. (1987). Ecology of macroalgae in North Inlet, South Carolina. Ph.D. dissertation, University of South Carolina, Columbia

Dame, R., Chrzanowski, R., Bildstein, K., Kjerfve, B., McKellar, H., Nelson, D., Spurrier, J., Stancyk, S., Stevenson, H., Vernberg, F., Zingmark, R. (1986). The outwelling hypothesis and North Inlet, South Carolina. Mar. Ecol. Prog. Ser. 33: 217-229

Dame, R., Kenny, P. (1986). Variability of Spartina alterniflora primary production in the euhaline North Inlet estuary. Mar. Ecol. Prog. Ser. 32: 71-80

Dame, R., Spurrier, J., Wolaver, T. (1989). Carbon, nitrogen and phosphorus processing by an oyster reef. Mar. Ecol. Prog. Ser. 54: 249-256

Dame, R., Wolaver, T., Spurrier, J., Miller, A. (1990). The Bly Creek ecosystem study - phosphorus exchange within a euhaline salt marsh basin, North Inlet, South Carolina. Neth. J. Sea Res. 27: in press

Dame, R., Zingmark, R., Haskin, E. (1984). Oyster reefs as processors of estuarine materials. J. exp. mar. Biol. Ecol. 83: $239-247$

Day, J., Smith, W., Wagnet, P. (1973). Community structure and carbon budget of a salt marsh and shallow bay estuarine system in Louisiana. Center for Wetland Resources, Publ. No. LSU-SG-72-04. Louisiana State University, Baton Rouge

D'Elia, C., Steudler, P., Corwin, A. (1977). Determination of total nitrogen in aqueous samples using persulfate digestion. Limnol. Oceanogr. 22: 760-764

Eiser, W., Kjerfve, B. (1986). Marsh topography and hypsometric characteristics of a South Carolina salt marsh basin Estuar. coast. Shelf Sci. 23: 595-605

Fisher, R., Carlson, P., Barber, R. (1982). Sediment nutrient regeneration in three North Carolina estuaries. Estuar coast. Shelf. Sci. 14: 101-116

Gallagher, J., Pfeiffer, W., Pomeroy, L. (1976). Leaching and microbial utilization of dissolved organic matter from leaves of Spartina alterniflora. Estuar. coast. mar. Sci. 4 . $467-471$

Gardner, R., Bohn, M. (1980). Geomorphic and hydraulic evolution of tidal creeks on a subsiding beach ridge plain, North Inlet, S.C. Mar. Geol. 34: M91-M97

Glibert, P., Loder, T. (1977) Automated analysis of nutrients in 
sea water Woods Hole Oceanogr. Inst. Tech. Rep. WHOI$77-47,47 \mathrm{p}$

Glover, L., Morris, I. (1979). Photosynthetic carboxylating enzymes in marine phytoplankton. Limnol. Oceanogr. 23: 80-89

Haines, E., Chalmers, A., Hanson, R., Sherr, B. (1977). Nitrogen pools and fluxes in a Georgia salt marsh. In: Wiley, M. (ed.) Estuarine processes, Vol. 2. Academic Press, New York, p. 241-254

Hopkinson, C. (1985). Shallow-water benthic and pelagic metabolism: evidence of heterotrophy in the near-shore Georgia Bight. Mar. Biol. 87: 18-32

Howarth, R. (1988). Nutrient limitation of net primary produc tion in marine ecosystems. A. Rev. Ecol. Syst. 19: 89-110

Howes, B., Dacey, J., Teal, J. (1985). Annual carbon mineralization and belowground production of Spartina alterniflora in a New England salt marsh. Ecology 66: 595-605

Jordan, T., Correll, D. (1985). Nutrient chemistry and hydrology of interstitial water in brackish tidal marshes of Chesapeake Bay. Estuar. coast. Shelf Sci. 21: 45-55

Jordan, T., Correll, D. (1986). Flux of particulate matter in the tidal marshes and subtidal shallows of the Rhode River Estuary. Estuaries 9: 310-319

Kjerfve, B. (1982). Calibration of estuarine current crosses Estuar. coast. Shelf Sci. 15: 553-559

Kjerfve, B., Wolaver, T. (1988). Sampling optimization for studies of tidal transport in estuaries. Am. Fish. Soc. Symp. 3: $26-33$

Mallows, C. (1973). Some comments on Cp. Technometrics 16: $661-675$

Morris, J., Whiting, G. (1986). Emission of gaseous carbon dioxide from salt marsh sediments and its relation to other carbon losses. Estuaries 9: 9-19

Murphy, J., Riley, J. (1962). A modified single solution method for the determination of phosphate in natural waters. Anal. Chim. Acta 27: 30

Nixon, S. (1980). Between coastal marshes and coastal waters - a review of twenty years of speculation and research on the role of salt marshes in estuarine productivity and water chemistry. In: Hamilton, P., MacDonald, K. (eds.) Estuarine and wetland processes. Plenum Press, New York, p. 437-525

Nixon, S., Oviatt, C., Hale, S. (1976). Nitrogen regeneration and the metabolism of coastal marine bottom communities. In: Anderson, J., Macfadyen, A. (eds.) The role of terrestrial and aquatic organisms in decomposition processes. Blackwell Scientific, London, p. 269-283

Odum, E. (1969). The strategy of ecosystem development. Science 164: 262-270

Ornes, H., Kaplan, D. (1989). Macronutrient status of tall and short forms of Spartina alterniflora in a South Carolina salt marsh. Mar. Ecol. Prog. Ser. 55: 63-72

Pakulski, J. (1986). The release of reducing sugars and dissolved organic carbon from Spartina alterniflora Loisel in a Georgia salt marsh. Estuar. coast. Shelf Sci. 22: 385-394

Parshall, R. (1950). Measuring water in irrigation channels with Parshall flumes and small weirs. U.S. Soil Conservation Service Cir. 843

Pearl, H. (1985). Microzone formation: its role in the enhancement of aquatic $\mathrm{N}_{2}$ fixation. Limnol. Oceanogr. 30: $1246-1252$

Pomeroy, L., Bancroft, K., Breed, J., Christian, R., Frankenberg, D., Hall, J., Maurer, L., Wiebe, W., Wiegert, R. Wetzel, R. (1977). Flux of organic matter through a salt marsh. In: Wiley, M. (ed.) Estuarine processes, Vol. 2 Academic Press, New York, p. 270-279

Pomeroy, L., Wiegert, R. (1981). The ecology of a salt marsh Springer Verlag, New York
Redfield, A., Ketchum, B., Richards, F. (1963). The influence of organisms on the composition of seawater. In: Hill, M. (ed.) The sea, Vol. 2. Interscience, New York, p. 26-77

Roman, C., Daiber, F. (1989). Organic carbon flux through a Delaware Bay salt marsh: tidal exchange, particle size distribution, and storms. Mar Ecol. Prog. Ser. 54: 149-156

Ryther, J., Dunstan, W (1971). Nitrogen, phosphorus, and eutrophication in the coastal marine environment. Science 171: $1008-1013$

Schindler, D. (1981). Studies of eutrophication in lakes and their relevance to the estuarine environment. In: Neilson, B., Cronin, L. (eds.) Estuaries and nutrients. Humana Press, Clifton, New Jersey, p. 71-82

Sellner, K., Zingmark, R., Miller, T. (1976). Interpretations of the ${ }^{14} \mathrm{C}$ method of measuring total annual primary production of phytoplankton in a South Carolina estuary. Botanica mar. 19: 119-125

Settlemyre, J., Gardner, L. (1977). Suspended sediment flux through a salt marsh drainage basin. Estuar. coast. mar. Sci. 5: 653-663

Solorzano, L. (1969). Determination of ammonia in natural waters by the phenolhypochlorite method. Limnol. Oceanogr. 14: 799-801d

Spurrier, J., Kjerfve, B. (1988). Estimating the net flux of nutrients between a salt marsh and a tidal creek. Estuaries 11: $10-14$

Smith, S. (1984). Phosphorus versus nitrogen limitation in the marine environment. Limnol. Oceanogr. 29: 1149-1160

Teal, J. (1962). Energy flow in the salt marsh ecosystem of Georgia. Ecology 43: 614-624

Turner, R. (1978). Community plankton respiration in a salt marsh estuary and the importance of macrophyte leachates. Limnol. Oceanogr. 23: 442-451

Valiela, I., Costa, J. (1988). Eutrophication of Buttermilk Bay, a Cape Cod coastal embayment: concentrations of nutrients and watershed nutrient budgets. Envir. Mgmt 12: 539-553

Valiela, I., Teal, J. (1979). The nitrogen budget of a salt marsh ecosystem. Nature, Lond. 280: 652-656

Valiela, I., Teal, J., Volkman, J., Shafer, D., Carpenter, J. (1978). Nutrient and particulate fluxes in a salt marsh ecosystem: tidal exchanges and inputs of precipitation and groundwater. Limnol. Oceanogr. 23: 798-812

Vitousek, P., Reiners, W. (1975). Ecosystem succession and nutrient retention: a hypothesis. Bioscience 25: 376-381

Ward, L. (1981). Suspended-material transport in marsh tidal channels, Kiawah Island, South Carolina. Mar. Geol. 40 139-154

Whiting, G., Childers, D. (1989). Subtidal advective water flux as a potentially important nutrient input to southeastern U.S.A. saltmarsh estuaries. Estuar. coast. Shelf Sci. 28: $417-431$

Whiting, G., McKellar, H., Spurrier, J., Wolaver, T. (1989). Nitrogen exchange between a portion of vegetated salt marsh and the adjoining creek. Limnol. Oceanogr. 34: $463-473$

Whiting, G., Morris, J. (1986). Nitrogen fixation $\left(\mathrm{C}_{2} \mathrm{H}_{2}\right.$ reduction) in a salt marsh: its relationship to temperature and an evaluation of an in situ chamber technique. Soil. Biol. Biochem. 18: 515-521

Whitney, D., Chalmers, A., Haines, E., Hanson, R., Pomeroy, L., Sheer, B. (1981). The cycles of nitrogen and phosphorus. In: Pomeroy, L., Wiegert, R. (eds.) The ecology of a salt marsh. Springer, New York, p. 163-181

Williams, T., Wolaver, T., Dame, R., Spurrier, J. (1991). The Bly Creek ecosystem study - organic carbon exchange within a salt marsh basin, North Inlet, SC. J. exp. mar. Biol. Ecol. (in press) 
Wolaver, T., Dame, R., Spurrier, J., Miller, A. (1988a). Sediment exchange between a euhaline salt marsh in South Carolina and the adjacent tidal creek. J. coast. Res. 4: $17-26$

Wolaver, T., Dame, R., Spurrier, J., Miller, A. (1988b). Bly Creek ecosystem study - inorganic sediment transport within an euhaline salt marsh basin, North Inlet, South Carolina. J. coast. Res. 4: 607-615

Wolaver, T., Johnson, W., Marozas, M. (1984). Nitrogen and phosphorus concentrations with North Inlet, South Carolina - speculation as to sources and sinks. Estuar. coast. Shelf Sci. 19: 243-255

Wolaver, T., Spurrier, J. (1988). Carbon transport between a euhaline vegetated marsh in South Carolina and the adjacent tidal creek: contributions via tidal inundation, runoff and seepage. Mar. Ecol. Prog. Ser. 42: 53-62

Wolaver, T., Whiting, G., Dame, R., Williams, T., Spurrier, J. (1988c). Bly Creek ecosystem study - nitrogen exchange

This article was submitted to the editor within a euhaline salt marsh basin of North Inlet, South Carolina. Mar. Ecol. Prog. Ser, 49: 107-116

Wolaver, T., Whiting, G., Kjerfve, B., Spurrier, J., McKellar, H., Dame, R., Chrzanowski, T., Zingmark, R., Williams, T. (1985). The flume design - a methodology for evaluating material fluxes between a vegetated salt marsh and the adjacent tidal creek. J. exp. mar. Biol. Ecol. 91: 281-291

Wolaver, T., Williams, T. (1986). Stream water chemistry of a small forested watershed on the South Carolina coast. Southeast. Geol. 27: 45-52

Woodwell, G., Whitney, D., Hall, C., Houghton, R. (1977). The Flax Pond ecosystem study: exchange of carbon in water between a salt marsh and Long Island Sound. Limnol. Oceanogr. 22: 823-828

Yelverton, G., Hackney, C. (1986). Flux of dissolved organic carbon and pore water through the substrate of a Spartina alterniflora marsh in North Carolina. Estuar. coast. Shelf Sci. 22: $255-267$

Manuscript first received: July 31, 1990

Revised version accepted: March 6, 1991 